\title{
ASSESSMENT ON IMPACT OF COVID 19 PANDEMIC ON FEAR AND SOCIOECONOMIC STATUS AMONG SOUTH INDIAN POPULATION
}

\author{
SREEJA NYAYAKAR, MUTHUKUMAR M., LATHA SREE MOOTHI
}

Department of Pharmacy Practice, Hillside College of Pharmacy and Research Centre, Bangalore, Karnataka, India

Email: sreejanyayakar999@gmail.com

Received: 13 Aug 2020, Revised and Accepted: 06 Oct 2020

\section{ABSTRACT}

Objective: To assess the impact of the COVID 19 pandemic on fear and socioeconomic status among the south Indian population.

Methods: A prospective observational cross-sectional study was conducted on 18-year old and older people who are willing to fill the online form were included in the study. People who are not willing to fill the form and those who filled the forms incompletely were excluded from the study. Microsoft Excel was used for recording and analyzing the data of recruited subjects. Descriptive statistical analyses were used to calculate the average and standard deviation.

Results: In total 476 respondents were included in the study to make the results. From the 476 respondents, $53.9 \%$ were males and $43.4 \%$ were females, $43.4 \%$ of individuals were satisfied with family life, $31.7 \%$ of individuals were satisfied with their salary, $37.3 \%$ of individuals were satisfied with their economic position, $55.2 \%$ of individuals were satisfied with their health and $50.4 \%$ of individuals were satisfied with their life in general.

Conclusion: Our study concludes that young students are showing more interest in online surveys among other general populations and data concludes that fear about the infection was less among the study population. More than half of the participants are concerned about their salary and most of the participants are not feared about their family life and their health.

Keywords: COVID 19, Fear, Socio-economic, Prospective

(C) 2020 The Authors. Published by Innovare Academic Sciences Pvt Ltd. This is an open access article under the CC BY license (http://creativecommons.org/licenses/by/4.0/) DOI: http://dx.doi.org/10.22159/ijpps.2020v12i12.39381. Journal homepage: https://innovareacademics.in/journals/index.php/ijpps.

Speedy peer review was done as the subject of the manuscript was related with pandemic.

\section{INTRODUCTION}

Coronavirus disease 2019(COVID 19) has taken just three months to spread all over the world from the first case reported in the city of Wuhan, china on of Hubei Province, on December 12, 2019 [1] and SARS COV-2 was first isolated and identified from pneumonia patient belonging to Wuhan china which is responsible for causing the COVID 19 in human beings [2]. The world health organization declared a new coronavirus which causing COVID 19 disease is a public health emergency of international concern [3]. People in various regions of world are worried about the spread of coronavirus, which has a relatively high risk of death [4].

Fear is an emotional expression induced by the threat-related stimuli to get adaptive behaviors to avoid or cope with that threat [5]. Fear helps to enhance public adherence towards safety behavior such as social distancing, hand washing. But at the same time, the excessive fear will have effects on both individual levels like mental health problems and as well as society level like panic shopping [6].

On 2 August 2020, in India, 1,695,988 corona virus-infected cases were reported by the Ministry of Health and Family Welfare (MoHFW) [7]. In the absence of a vaccine available for the coronavirus, the government takes quarantine measures such as hospitalized quarantine for positive cases and isolation for the tracing contacts as the only way of strategy to stop the coronavirus spread. This method of quarantine increases the fear of life as well as economic situation [8].

This quarantine process, due to a pandemic situation the people were instructed to stay home for an indefinite period, the different orders and messages from health authorities and government increase the fear among people [9]. The health of the public will be at risk if they failure to follow government guidelines [10]. Social media like Facebook, Whatsup, Wechat, Twitter, Skype, etc., plays a major role in providing information regarding the pandemic. So, social media platforms can improve people's knowledge related to coronavirus and also enhance people's stigmatization mentality as well as fear [4].
Uninfected people get more fear towards the coronavirus than infected individual and their contact persons which increase stigmatization. This behavior increases the risk of developing mental health problems in society [1]. This kind of stigmatization and fear will affect the outcome of the pandemic spread control measures which is already seen in SARS and Ebola outbreaks [4].

The fear of coronavirus infection is very high when the risk of a loved one for infection increases. During the pandemic, people get more mental health problems when they start concerning the health of loved ones, and mainly if they are at high risk like co-morbidities get infected, then the fear about the coronavirus increases many folds [6]. Mainly among the young adult population, this continuous lockdown measure, lifestyle disruption, and many stressful life events have created hopelessness and affected long time well-being [11].

Multiple cases were reported in different cities in India, so the Government of India took necessary action by announcing a lockdown in every corner of the country. The metropolises of Delhi, Mumbai, Ahmadabad, Kolkata, Chennai are densely populated, which has given rise to a spurt in cases of COVID-19 and these are the cities which are engines for growth and development of the Indian economy. The pandemic has led the socioeconomic disruption, inhibiting the growth of the entire economic environment [12]. COVID 19 pandemic has bought a negative impact on the economy of China and other nations [13].

Coronavirus disease has become a world-changing event and is not only a humanitarian crisis but also an economic and social crisis. Its impact on the business environment is worldwide. Due to the rapid spread of the coronavirus, several entities are bound to limit their business operations leading to disruption in the economic activities of several industries that drives growth. An increase in the unemployment level due to job loss of several employees and measures like pay cuts had reduced the purchasing power of the people [12]. The main objectives of our study include to analyze the 
demographic details of respondents involved in the study, to evaluate the mental health status of individuals in terms of fear by using the fear scale developed and validated by the International journal of mental health and addiction, and to evaluate the socioeconomic status and extent of demographic variables on the socioeconomic status of individuals

\section{MATERIALS AND METHODS}

\section{Study design}

Prospective observational cross-sectional study.

\section{Study population}

$18 \mathrm{y}$ old and older people who are willing to fill the online form were included in the study. People who are not willing to fill the form and those who filled the forms incompletely were excluded from the study.

\section{Data instrument}

Socio-demographic data were collected on sex, age, education, employment status, residential location, and information regarding
COVID 19 was collected. Fear and socioeconomic status were collected by using the validated questionnaire.

\section{Sample size}

Estimated sample size is 500

\section{Statistical analysis}

Microsoft Excel was used for recording and analyzing the data of recruited subjects. Descriptive statistical analyses were used to calculate the average and standard deviation.

\section{RESULTS AND DISCUSSION}

In this study, respondents were recruited through online Google forms using social media platforms like Whatsup, Telegram, and LinkedIn. In total, 600 respondents provided consent to participate in the study but 124 did not fill the form so finally, we included the 476 respondents for our study to make the results. $47.8 \%$ of respondents are students in our study. $41.59 \%$ of respondents are residents of state Andhra Pradesh. In our 50.6\% of respondents were health care professionals.

Table 1: Demographic details of the study population

\begin{tabular}{|c|c|c|}
\hline Variables & Values in number & Values in \% \\
\hline \multicolumn{3}{|l|}{ Gender } \\
\hline Males & 257 & 53.9 \\
\hline Females & 219 & 43.1 \\
\hline \multicolumn{3}{|l|}{ Age (in years) } \\
\hline $18-27$ & 356 & 74.7 \\
\hline $28-37$ & 68 & 14.2 \\
\hline $38-47$ & 27 & 5.6 \\
\hline $48-57$ & 20 & 4.2 \\
\hline $58-67$ & 5 & 1 \\
\hline \multicolumn{3}{|c|}{ Educational Qualification } \\
\hline Less than high school & 15 & 3.1 \\
\hline High school/Diploma & 120 & 25.2 \\
\hline UG & 168 & 35.2 \\
\hline PG & 163 & 34.4 \\
\hline $\mathrm{PhD}$ & 10 & 2.1 \\
\hline \multicolumn{3}{|l|}{ Employment status } \\
\hline Employed & 129 & 27.1 \\
\hline Freelancer & 9 & 1.8 \\
\hline Homemaker & 19 & 3.9 \\
\hline Retired & 17 & 3.5 \\
\hline Self Employed & 36 & 7.5 \\
\hline Students & 228 & 47.89 \\
\hline Unemployed & 38 & 7.9 \\
\hline \multicolumn{3}{|l|}{ State } \\
\hline Andhra Pradesh & 198 & 41.59 \\
\hline Kerala & 38 & 7.9 \\
\hline Maharashtra & 20 & 4.2 \\
\hline Tamil Nadu & 47 & 9.8 \\
\hline Telangana & 36 & 7.5 \\
\hline Others & 138 & 28.99 \\
\hline \multicolumn{3}{|c|}{ Are you health care professional } \\
\hline Yes & 241 & 50.63 \\
\hline No & 235 & 49.36 \\
\hline
\end{tabular}

In our study, $28.7 \%$ of respondents were working from the Home, $21.4 \%$ were working on-site, $21.4 \%$ of respondents were stopped working due to crisis, and $6.9 \%$ were lost their jobs due to crisis. At the time of data collection, in the total 476 respondents, $3.1 \%$ of people were infected with COVID.

Table 2 gives the information regarding the fear scale, $36.9 \%$ of individual's response is neutral for the item 1 calculated mean and standard deviation is $2.9+1.06,29.2 \%$ of individuals response is neutral for item 2 calculated mean and standard deviation is
$2.9+1.22,37.3 \%$ of individuals were given the responsibility of disagreeing for the item 3 calculated mean and standard deviation is $2.03+1.05,31 \%$ of individuals were given the responsibility of disagreeing for the item 4 calculated mean and standard deviation is $2.35+1.19,25.6 \%$ of individual's response is neutral for the item 5 calculated mean and standard deviation is $2.61+1.24,38 \%$ of individuals were given the responsibility of disagreeing for the item 6 calculated mean and standard deviation is $2.0+1.0$ and $35.9 \%$ of individuals were given the responsibility of disagreeing for the item 7 calculated mean and standard deviation is $2.15+1.11$. 


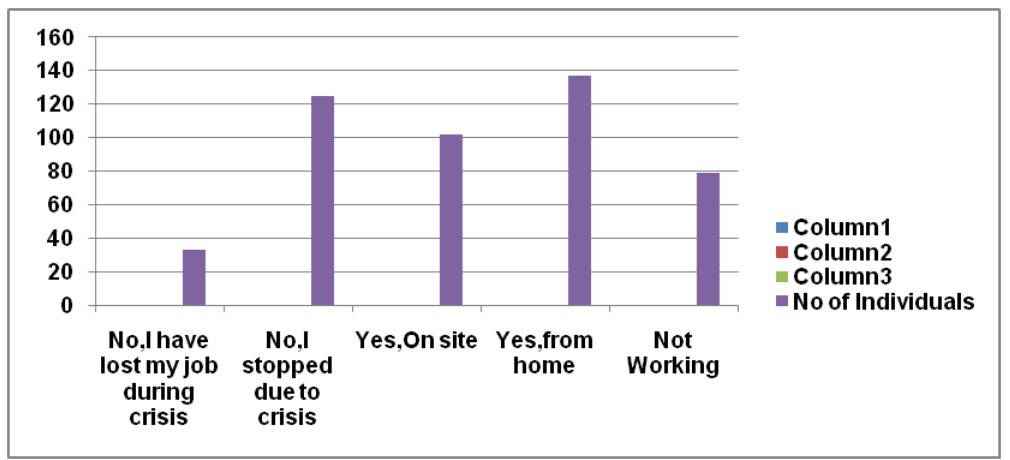

Fig. 1: Working status of respondents

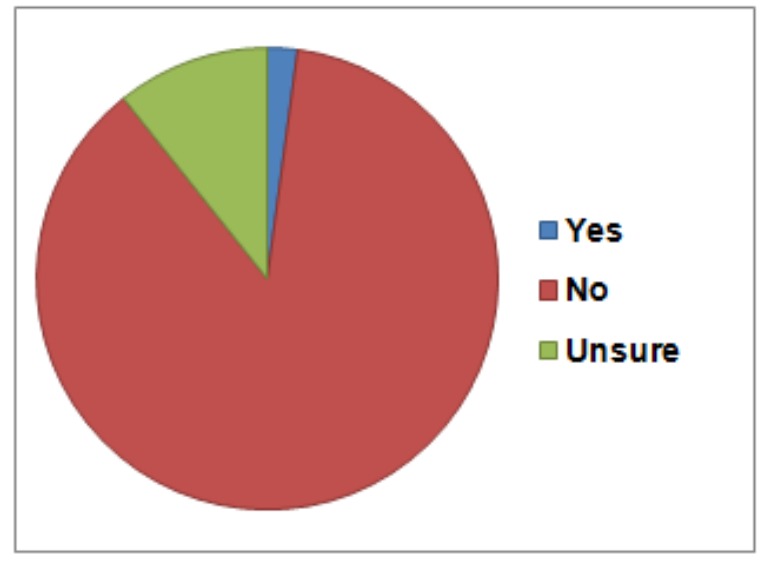

Fig. 2: Respondents affected with COVID 19

Table 2: Assesment of fear scale

\begin{tabular}{|c|c|c|c|c|c|c|c|c|}
\hline Fear scale & Agree (\%) & Disagree (\%) & Neutral (\%) & Strongly disagree (\%) & Strongly agree (\%) & Mean & SD & Skewness \\
\hline Item 1 & $103(21.6)$ & $84(17.6)$ & $176(36.9)$ & $73(15.3)$ & $40(8.4)$ & 2.90 & 1.06 & -0.077 \\
\hline Item 2 & $124(26.0)$ & $85(17.8)$ & $139(29.2)$ & $43(9)$ & $85(17.8)$ & 2.90 & 1.22 & -0.106 \\
\hline Item 3 & $31(6.5)$ & $178(37.39)$ & 77 (16.1) & $173(36.3)$ & $17(3.5)$ & 2.03 & 1.05 & 1.005 \\
\hline Item 4 & $63(13.2)$ & $148(31)$ & $99(20.7)$ & $139(29.2)$ & $27(5.6)$ & 2.35 & 1.19 & 0.578 \\
\hline Item 5 & $91(19.1)$ & $113(23.7)$ & $122(25.6)$ & $115(24.1)$ & $35(7.3)$ & 2.61 & 1.24 & 0.227 \\
\hline Item 6 & $24(5)$ & $181(38)$ & $83(17.4)$ & $173(36.3)$ & $15(3.1)$ & 2.00 & 1.01 & 1.013 \\
\hline Item 7 & $48(10)$ & $171(35.9)$ & $80(16.8)$ & 158 (33.1) & $19(3.9)$ & 2.15 & 1.11 & 0.824 \\
\hline
\end{tabular}

\section{Assessment of the socio-economic status of respondents}

Table 3 describes the impact of COVID 19 on the socioeconomic status of individuals. Results show that $43.4 \%$ of individuals are satisfied with family life, $46.2 \%$ of individuals are satisfied with their leisure time, $31.7 \%$ of individuals are satisfied with their salary, $37.3 \%$ of individuals are satisfied with their economic position, $33.8 \%$ of individuals are satisfied with their pay and fringe benefits, $55.2 \%$ of individuals are satisfied with their health and 50.4\% of individuals are satisfied with their life in general.

Table 3: Socioeconomic statuses of respondents

\begin{tabular}{|c|c|c|c|c|c|}
\hline Socioeconomic status & Can't say (\%) & Dissatisfied (\%) & Satisfied (\%) & Very dissatisfied (\%) & Very satisfied (\%) \\
\hline Your Family life & $79(16.5)$ & $31(6.5)$ & $207(43.4)$ & $23(4.8)$ & $136(28.5)$ \\
\hline Your Leisure time & $86(18.0)$ & $47(9.8)$ & $220(46.2)$ & $26(5.4)$ & $97(20.3)$ \\
\hline Your savings & 133 (27.9) & $83(17.4)$ & 151 (31.7) & $63(13.2)$ & $46(9.6)$ \\
\hline Your Salary & $162(34)$ & $86(18)$ & $121(25.4)$ & $69(14.4)$ & $38(7.9)$ \\
\hline Your Economic Position & $121(25.4)$ & $72(15.1)$ & $178(37.3)$ & $59(12.3)$ & $46(9.6)$ \\
\hline Your pay and fringe benefits & $152(31.9)$ & $78(16.3)$ & $161(33.8)$ & $48(10)$ & $37(7.7)$ \\
\hline Your Health & $53(11.1)$ & $20(4.2)$ & $263(55.2)$ & $13(2.7)$ & $127(26.68)$ \\
\hline Your life, in general & $86(18)$ & $34(7.1)$ & $240(50.4)$ & $30(6.3)$ & $86(18)$ \\
\hline
\end{tabular}

Table 4 gives information regarding the extent of demographic variables on the socioeconomic status of individuals. It shows that the majority of the females are satisfied with their family life, but when compared to females, males are more satisfied with their family life. The majority of the females are satisfied with their leisure time but when compared to males, females are more 
satisfied with females; males are more satisfied with their savings. The majority of females and males cannot say about their salary. The majority of the females are satisfied with their economic position, but when compared to females, males are more satisfied with their economic position. The majority of the females are cannot say with their pay and fringe benefits but when compared to females, males are more satisfied with their pay and fringe benefits.

Table 4: Extent of demographic variables on the socioeconomic status of individuals

\begin{tabular}{|c|c|c|c|c|c|c|c|c|}
\hline \multirow[t]{4}{*}{ Questionnaire } & \multirow[t]{4}{*}{ Socioeconomic status } & \multicolumn{2}{|l|}{ Gender } & \multicolumn{5}{|l|}{ Age } \\
\hline & & Males & Females & $18-27$ & 28-37 & $38-47$ & 48-57 & $58-67$ \\
\hline & & $n=257$ & $n=219$ & $n=356$ & $N=68$ & $\mathrm{~N}=\mathbf{2 7}$ & $n=20$ & $N=5$ \\
\hline & & $(\%)$ & $(\%)$ & $(\%)$ & $(\%)$ & $(\%)$ & $(\%)$ & $(\%)$ \\
\hline Your Family & Can't Say & $34(13)$ & $45(20)$ & $67(19)$ & $7(10)$ & $3(11)$ & $2(10)$ & 0 \\
\hline \multirow[t]{4}{*}{ life } & Dissatisfied & $58(23)$ & $12(5)$ & $22(6)$ & $6(9)$ & $3(11)$ & 0 & 0 \\
\hline & Satisfied & $19(7)$ & $96(44)$ & $165(46)$ & $23(34)$ & $8(30)$ & $8(40)$ & $3(60)$ \\
\hline & Very Dissatisfied & $111(43)$ & $8(4)$ & $17(5)$ & $4(6)$ & $1(4)$ & $1(5)$ & 0 \\
\hline & Very Satisfied & $78(30)$ & $58(27)$ & $85(24)$ & $28(41)$ & $12(44)$ & $9(45)$ & $2(40)$ \\
\hline \multirow{5}{*}{$\begin{array}{l}\text { Your Leisure } \\
\text { time }\end{array}$} & Can't Say & $55(21)$ & 31 (14) & 69 (19) & $9(13)$ & $4(15)$ & $4(20)$ & 0 \\
\hline & Dissatisfied & $21(8)$ & $26(12)$ & $35(10)$ & $9(13)$ & 3 (11) & 0 & 0 \\
\hline & Satisfied & $113(44)$ & 107 (49) & $169(47)$ & $32(48)$ & $10(37)$ & $7(35)$ & $2(40)$ \\
\hline & Very Dissatisfied & $14(5)$ & $12(5)$ & $18(5)$ & $7(10)$ & 0 & $1(5)$ & 0 \\
\hline & Very Satisfied & $54(21)$ & $45(20)$ & $65(18)$ & $11(16)$ & $10(37)$ & $1(5)$ & $3(60)$ \\
\hline \multirow[t]{5}{*}{ Your savings } & Can't Say & $74(29)$ & 59 (27) & $105(30)$ & $16(24)$ & $6(22)$ & $5(25)$ & $1(10)$ \\
\hline & Dissatisfied & $41(16)$ & $42(19)$ & $70(20)$ & $10(15)$ & $2(7)$ & $1(5)$ & 0 \\
\hline & Satisfied & $87(34)$ & $64(29)$ & $102(29)$ & $28(41)$ & $13(48)$ & $6(30)$ & $2(40)$ \\
\hline & Very Dissatisfied & $34(13)$ & $29(13)$ & $55(15)$ & $7(10)$ & $1(4)$ & 0 & 0 \\
\hline & Very Satisfied & $21(8)$ & $25(12)$ & $24(6)$ & $7(10)$ & $5(19)$ & $8(40)$ & $2(40)$ \\
\hline \multirow[t]{5}{*}{ Your Salary } & Can't Say & $84(34)$ & $78(36)$ & 139 (39) & $13(19)$ & $7(26)$ & $2(10)$ & $1(20)$ \\
\hline & Dissatisfied & $48(18)$ & $38(17)$ & $65(18)$ & $17(25)$ & $2(7)$ & $2(10)$ & 0 \\
\hline & Satisfied & $73(28)$ & $48(22)$ & $78(22)$ & 19 (28) & $13(48)$ & $9(45)$ & $2(40)$ \\
\hline & Very Dissatisfied & $33(13)$ & $36(16)$ & $59(17)$ & $9(13)$ & 0 & $1(5)$ & 0 \\
\hline & Very Satisfied & $19(7)$ & $19(9)$ & $15(4)$ & $10(15)$ & $5(19)$ & $6(30)$ & $2(40)$ \\
\hline Your Economic & Can't Say & $69(27)$ & $52(25)$ & 99 (27) & $11(16)$ & $6(22)$ & $5(25)$ & 0 \\
\hline \multirow[t]{4}{*}{ Position } & Dissatisfied & $37(14)$ & $35(16)$ & $61(17)$ & $6(9)$ & $2(7)$ & $2(10)$ & $1(20)$ \\
\hline & Satisfied & $100(39)$ & $78(36)$ & $129(36)$ & $31(46)$ & $12(44)$ & $4(20)$ & $2(40)$ \\
\hline & Very Dissatisfied & $27(11)$ & $32(15)$ & $50(14)$ & $9(13)$ & 0 & 0 & 0 \\
\hline & Very Satisfied & $24(9)$ & $22(10)$ & $17(4)$ & $11(16)$ & $7(26)$ & $9(45)$ & $2(40)$ \\
\hline Your pay and & Can't Say & $82(31)$ & $70(32)$ & $125(35)$ & 19 (28) & $6(22)$ & $2(10)$ & 0 \\
\hline \multirow[t]{4}{*}{ fringe benefits } & Dissatisfied & $38(15)$ & $40(18)$ & $60(17)$ & $12(18)$ & $2(7)$ & $3(15)$ & $1(20)$ \\
\hline & Satisfied & $94(37)$ & $67(31)$ & $111(31)$ & $27(40)$ & $13(49)$ & $7(35)$ & $3(60)$ \\
\hline & Very Dissatisfied & $21(8)$ & $27(12)$ & $41(12)$ & $5(7)$ & 0 & $2(10)$ & 0 \\
\hline & Very Satisfied & $22(9)$ & $15(7)$ & $19(5)$ & $5(7)$ & $6(22)$ & $6(30)$ & $1(20)$ \\
\hline \multirow{5}{*}{$\begin{array}{l}\text { Your life, in } \\
\text { general }\end{array}$} & Can't Say & $48(18)$ & 38 (17) & 68 (19) & $11(16)$ & $3(11)$ & $3(15)$ & $1(20)$ \\
\hline & Dissatisfied & $16(6)$ & $18(8)$ & $26(7)$ & $3(4)$ & $3(11)$ & $2(10)$ & 0 \\
\hline & Satisfied & 125 (49) & $115(53)$ & $184(52)$ & $36(53)$ & $11(41)$ & $6(30)$ & $3(60)$ \\
\hline & Very Dissatisfied & $15(6)$ & $15(7)$ & $20(6)$ & $7(10)$ & $1(4)$ & $2(10)$ & 0 \\
\hline & Very Satisfied & $53(21)$ & $33(15)$ & $58(16)$ & $11(16)$ & $9(33)$ & $7(35)$ & $1(20)$ \\
\hline \multirow[t]{5}{*}{ Your Health } & Can't Say & $27(10)$ & $26(11)$ & $38(11)$ & $6(9)$ & $7(26)$ & $2(10)$ & 0 \\
\hline & Dissatisfied & $7(3)$ & $13(6)$ & $13(4)$ & $5(7)$ & $1(4)$ & 0 & $1(20)$ \\
\hline & Satisfied & $134(52)$ & 129 (59) & 205 (58) & $38(56)$ & $10(37)$ & $8(40)$ & $2(40)$ \\
\hline & Very Dissatisfied & $5(2)$ & $8(4)$ & $6(2)$ & $3(4)$ & 0 & $3(15)$ & $1(20)$ \\
\hline & Very Satisfied & $84(33)$ & $43(20)$ & $94(26$ & $16(24)$ & $9(33)$ & $7(35)$ & $1(2$ \\
\hline
\end{tabular}

When it comes to the extent of age distribution on the socioeconomic status of respondents, the majority of respondents with age group 18-27 are more satisfied with family life, leisure time, economic position, health, life in general but they cannot say about their savings and salary. The majority of respondents with the age group of 28-37 are very satisfied with their family life, satisfied with their leisure time, savings, salary, economic position, pay, and fringe benefits, health, and life in general. The majority of respondents with the age group of 38-47 are very satisfied with family life, satisfied with their leisure time, savings, salary, economic position, pay, and fringe benefits, health, and life in general. The majority of respondents with the age group of 48-57 are very satisfied with family life and life in general, cannot say about their economic position, satisfied with their leisure time, savings, salary, pay and fringe benefits, health.

Of the 476 respondents, $53.9 \%$ were males and $43.4 \%$ were females. More male respondents when compared to females. The age group with more number of respondents was observed as 18-27 y. In our study most of the respondents are with educational qualifications of UG and PG; the recent study also reports the same [1]. We analyzed that in our study, $28.7 \%$ of respondents were working from the Home, $21.4 \%$ were working on-site, $21.4 \%$ of respondents were stopped working due to crisis, and $6.9 \%$ were lost their jobs due to crisis. At the time of data collection, in the total 476 respondents, $3.1 \%$ of people were infected with COVID 19 and these results are supported by the study conducted by others [6]. Results obtained regarding the fear scale was supported by the other recent study [1] When it comes to the socioeconomic status the majority of the females are satisfied with their health, but when compared to males, females are more satisfied with their health. When it comes to life in general females are more satisfied when compared to males. The respondents in the age group of 58-67 are satisfied and very satisfied in the above aspects of life, health, family leisure time and savings.

\section{CONCLUSION}

Our study concludes that young students are showing more interest in online surveys, among other general populations. Results show that the various scales help to evaluate the impact of the pandemic on people's socioeconomic parameters and most of the people suffer 
from loss of employment due to the COVID pandemic, which showing much effect on their daily life. From the data we can conclude that fear about the Coronavirus infection was not more among our study population. The young age group involved in our study are satisfied with their family life, leisure time but facing some difficulties with the salary, savings during this pandemic. Future researches should be focused on assessing the impact of the pandemic on the economic status of the population.

\section{LIMITATIONS}

Due to the online collection of data, we lose the quality of data collection and due to the online data collection, there is a lack of trained interviewer to clarify the doubts regarding the data collection form and leads to less reliable data.

\section{ACKNOWLEDGMENT}

The authors would like to thank the management and staff of Hillside College of Pharmacy and Research center, Bangalore, and Dr. Manasa Rekha Ph. D. for their constant support and guidance.

\section{FUNDING}

Nil

\section{ABBREVIATION}

SARS COV severe acute respiratory syndrome coronavirus 2, MoHFW Ministry of Health and Family Welfare

\section{AUTHORS CONTRIBUTIONS}

All the authors have contributed equally

\section{CONFLICT OF INTERESTS}

Declared none

\section{REFERENCES}

1. Begum S, Emine GT, M Engin D, Seydi AS. Adaptation of the fear of COVID-19 scale: its association with psychological distress and life satisfaction in turkey. Int J Ment Health Addiction 2020. DOI:10.1007/s11469-020-00294-0

2. Niharika D, Niharika B, Aiswarya T, Nikitha A, Rabia B, Manal I, et al. Corona virus-a virus in learning. Int J Curr Pharm Res 2020;12:7-10.

3. Chitra BH, Rubiya SQ, Amola AJ. A review on COVID 19-a global battle between life and health. Int J Curr Pharm Res 2020;12:19-24.

4. Chung Ying Lin. Social reaction toward the 2019 novel coronavirus (COVID-19). Social Health Behavior 2020;3:1-2.

5. Ralph Adolphs. The biology of fear. Curr Biol 2013;23:1-33.

6. Gaetan M, Lotte G, Stefanie D, Elske S, Iris ME. Fear of the coronavirus (COVID-19): Predictors in an online study conducted in March 2020. J Anxiety Disorders 2020;74:1-8.

7. World Health Organization. Coronavirus Disease (COVID-19); 2020. Available from: https://www.who.int/india/ emergencies/novel-coronavirus-2019 [Last accessed on 10 Jul 2020]

8. Balaji KK, Sravendra R. COVID 19 in India: strategies to combat from combination threat of life and livelihood. J Microbiol Immunol Infect 2020;53:389-91.

9. Betty P, Carol SN. Mental health and covid-19 pandemic. N ENGL J Med 2020;383:510-2.

10. Farhan A, Turki A, Ahmed A, Khalid A, Kashifullah K. Knowledge attitude practices towards COVID 19 among residents in hail city, Saudi Arabia: a cross-sectional study. Asian J Pharm Clin Res 2020;13:147-52.

11. Lilly S, Annekatrin S, Laura B, Aja LM, Amy N, U Hepp, et al. Emotional distress in young adults during the COVID-19 pandemic: evidence of risk and resilience from a longitudinal cohort study. Psychological Medicine 2020;23:1-10.

12. Debdas R, Ananya P. Impact of covid-19 on sectors of Indian economy and business survival strategies. Int J Eng Management Res 2020;10:51-5.

13. Manjinder S, Manju N, Varinder S, Ameya S, Gitika AD, Paramjot $\mathrm{M}$, et al. COVID 19, epidemiology, pathogenicity, and global updates. Int J Appl Pharm 2020;12:16-28. 